\title{
The importance of evil for the under- standing of Freedom and its role in the emergence of the personality in Friedrich Schelling's Freiheitsschrift
}

RESUMEN: El objetivo de este artículo es presentar la idea de emergencia del ser humano ofrecida por Schelling en su Tratado de la esencia de la libertad humana. Se discurre sobre como el ser humano, alzándose desde el Fundamento de Dios, desde el primer momento se halla estrechamente entrelazado en la interacción entre el Fundamento y la Existencia de Dios, erigiéndose así como único ser de la Creación que posee la posibilidad esencial de elegir libremente el objeto de su voluntad. Además, el texto trata de mostrar que el mal es una condición necesaria tanto para que el ser humano sea capaz de ser libre como para moldear su personalidad.

PALABRAS CLAVE: SCHELLING; LIBERTAD; ŽIŽEK; MAL
ABSTRACT: The aim of this paper is to present Schelling's idea of the emergence of the human being in his Freedom Essay; namely, how human being, rising from the Ground of God, is from the very first moment interwined in the interplay of the Ground and the Existence of God becoming, thus, the only being of the Creation bearing the essential possibility of choosing freely what it wants to will. Furthermore, we will try to see how evil is a necessary condition for both human being's being able to be free and for the moulding of his personality. KEYWORDS: SCHELLING; FREEDOM; ŽIŽEK, EVIL 


\section{INTRODUCTION}

TN THIS PAPER OUR AIM IS to interpret the emergence of the human being in the Freiheitsschrift of Friedrich Schelling from an ontological point of view. What we intend to show is, first, how the human being emerges at the very centre of the Creation's dawn, in the violent split between the Ground and the Existence of God, holding, thus, strong bonds with Him, and, then, how during his ontic life, in his struggle to bring order and meaning to the world, he is guided-sometimes even torn- by the will of his making himself the centre of the existence and his becoming truly transparent in the light of the revelation of the Word. This ceaseless struggle is characterized, as we will see, by the emergence of evil expressed in the excessive lust for the selfhood by the human being and the rising of the personality as the constant interplay between the principles of the Ground and the Existence in the life of the human being. Finally, we will show how this endless struggle among the different forces guiding the will of the human being opens the way for the appearance of freedom, and for the latter's becoming the essential core of the human being's life and meaning.

More specifically, in the first part we will see how the violent and primordial split inside God among His Ground, His Existence and His uttering of the Word has opened the path first, for the emergence of the human being as such and his relation with God; second, for the former's possibility of striving for his return to the abyssal freedom of indifference which ruled before the two principles arose and started their radically oppositional struggle.

In the second part, we will continue with the interpretation of the emergence of the human being and we will show how his bonds with the Ground of God have planted the seed of an obscure, self-willing selfhood which, finally been brought forth into light by the revelation of the Word, is no longer a blind maniac will, but a clear will of the contraction of the self deeper and deeper into the Ground and the ardent desire of the human being to become one not with the centre of the existence, which is the Word, but with the centre of the Ground where the limitless contraction and the endless self-desire rule on their own shadow.

In the last part, we will try to unveil how evil appears as the consequence of the human being's being able to freely choose what he is and who he wants to be. Evil, far from being a mere privation or a mere dominance of the sensual faculties over the reason, will be interpreted as the choice of the human being to fully accomplish himself as the personality of the centre, as the Word uttered by the Ground, challenging with his every breath, thought and action the primacy of the revealed Word. 


\section{UTTERING THE SALVATION: THE DIVINE SPLIT OF GROUND AND EXISTENCE}

Friedrich Schelling is one of the philosophers who raised the potentiality and the importance of human being's actualization to a higher level, higher than any idea of understanding the human being as a pure cognizant subject whose aim would be to finally become completely transparent to himself and to the world through his becoming begotten by Reason. Human being, as presented in the Freiheitsschrift, is a being characterized by strong will, understanding the power of his selfhood, aware of his divine origin but, nevertheless, still free to choose whether $\Lambda$ ó $\gamma$ os, the Word, the revelation of the Divine, is to be safeguarded in the centre of the existence or else he reclaims for himself the right to be placed in the centre of the existence becoming, thus, the point of reference and the distorted core of his ontic and ontological existence. All of the above aspects are to be found in the work of the German philosopher, making the former a ground-breaking, frightful sometimes, insight into the innermost of the human being's essence. What is brought forth in every page is the power of human being's potentiality and the necessity to understand that in the depths of his own existence what makes of the human being what he is, is nothing else than his own freedom to become what he wants to become.

In order to comprehend what the human being is and how he came to emerge as a free actor, we must trace his origin back to God Himself and to the distinction made there between His Ground and Existence; a distinction which accompanies the whole text of the German philosopher and whose interplay is decisive for the human being's understanding of what acting freely means. According to Schelling,

God has in himself an inner ground of his existence that in this respect precedes him in existence; but, precisely in this way, God is again the prius [what is before] of the ground in so far as the ground, even as such, could not exist if God did not exist actu. (Schelling 2006, pp. 28)

This distinction is guiding, and will always be guiding, our motives, thoughts, actions and, finally, our seeking our own place in the world as well as having or not a possibility of ever considering this world as our abode. The way this violent separation between Ground and Existence in God is affecting and being shared with the human being's destiny is depicted by Slavoj Žižek in the following passage:

we are thereby again at the origins, in the absolute indifference: that is, the deepest essence of man is the abyss of freedom as pure indifference, as a willing which wants nothing. This means that - in so far as the universe qua multitude of entities 
effectively exists - the Absolute (God) Himself had to accomplish an analogous act on Himself: He had to disengage Himself from the primordial indifference and to posit the universe, reality. Man's act of decision, his step from the pure potentiality essentiality of a will which wants nothing to an actual will, is therefore a repetition of God's act: in a primordial act, God Himself had to 'choose Himself', His eternal character - to contract existence, to reveal Himself. In the same sense in which history is man's ordeal - the terrain in which humanity has to prove its creativity, to actualize its potential - nature itself is God's ordeal, the terrain in which $\mathrm{He}$ has to disclose Himself, to put His creativity to the test. (Žižek 2007, pp. 21)

What we can deduce from the above text is that the human being is connected to God through His distinction between Ground and Existence; we can also see that his "deepest essence" lies at the very origin of the absolute indifference- a state where the Will wants nothing. This umbilical cord is what ties the human being to a potential that is almost impossible to grasp in thought, let apart actualize it in actions and deeds. However, our origin lies exactly in that absolute indifference, in this abyssal freedom where all the willing wants nothing and the conflict cannot exist since it loses its meaning and potential in the absolute indifference. This absolute indifference that precedes every opposition, every duality and every conflict, is described by Schelling in the following extract:

there must be a being before all ground and before all that exists, thus generally before any duality-how can we call it anything other than the original ground or the non-ground [Ungrund]? Since it precedes all opposites, these cannot be distinguishable in it nor can they be present in any way. Therefore, it cannot be described as the identity of opposites; it can only be described as the absolute indifference [Indifferenz] of both. Most people forget, when they come to that point of examination where they must recognize a disappearance of all opposites, that these have now really disappeared, and they once again predicate the opposites as such as arising from the indifference which had emerged precisely due to their total cessation. Indifference is not a product of opposites, nor are they implicitly contained in it, but rather indifference is its own being separate from all opposition, a being against which all opposites ruin themselves, that is nothing else than their very not-Being [Nichtsein] and that, for this reason, also has no predicate, except as the very lacking of a predicate, without it being on that account a nothingness or non-thing. (Schelling 2006, pp. 69)

This absolute indifference, though, which from the first beginning of the human being becomes a goal to be sought for, offers no guarantee that, finally, it will be reached. The whole struggle of the human being, as a willing subject which does want something, if not everything, is at every single moment 
on a parallel path to the absolute indifference; the human being is doomed to struggle to reach the state of willing nothing only through his ceaseless willing something.

Coming back to the distinction between Ground and Existence which silences the absolute indifference through a scream of willing, Schelling is tracing it back to the possibility itself of human being's freedom and acting Evil. The reason why freedom, and Evil, originate from this violent split is that it is in this distinction we can trace the yearning of the God for Himself, His Ground always lurking as pure potentiality, and His coming into Light through the utterance of the Word, through his Self-revelation; a revelation founding human being's only possibility of coming to know himself and God, human being's only possibility of freely choosing his salvation in the uttered Word. This primordial struggle within God, between His potentiality of Being only for Himself, namely, of contracting Himself, nihilating every possibility of beings' emergence, and His expanding enlightening salvation offered through the utterance of the Word, set the absolutely terrifying ontological battleground of human being's origin and coming into emergence. This origin is the abyssal ground of our existence and of our being able to be free. Žižek interprets the root of our being able to be free and act evil, due to this split of Ground and Existence inside God, in the following way:

That is to say: the central tenet of 'Philosophical Investigations' is that if one is to account for the possibility of Evil, one has to presuppose a split of the Absolute itself into God in so far as He fully exists and the obscure, impenetrable Ground of his Existence - with the speculative audacity characteristic of his mode of thinking, Schelling locates the split which opens up the possibility of Evil in God Himself. This distinction between God's Existence and its Ground, between the Absolute in so far as it fully exists - in so far as it is posited as such, illuminated by the Light Reason - and the Absolute qua obscure longing [Sehnsucht] which strives for something outside itself without possessing a clear notion of what it actually strives for, means that God is not fully 'Himself' - that there is something in God which is not God. (Žižek 2007, pp. 61)

As a consequence of this split, the human being shares a strong bond with the dark longing of the Ground of God; nevertheless, while God exists as pure Light, understanding and revelation, the human being can decide to will something different from the revelation of the Word: his own being, his own self in the Ground, and as the Ground. This Ground is nothing else than the longing, the lust for oneself; a lust that in God exists only as potentiality while in the human being as the potentiality of a probable actualisable possibility. The human being may freely decide to long for himself, to will himself as everything that there is or that there should be. In the Ground the human 
being has finally found himself, he has found his selfhood, and from the very first moment of his becoming aware of his selfhood he is also aware of the opposite of his selfhood: the revelation of the Word and His all-embracing activity of bringing everything into the merging of salvation with Him. This is an ontological breakthrough of the highest significance made by Schelling since it shows a human being that from the very first moment of beginning is a being in dissonance and not in harmony. Quoting Žižek,

In short, by means of the Word, the subject finally finds himself, he is no longer a mere obscure longing for himself since, in the Word, he directly attains himself, posits himself as such, The price, however, is the irretrievable loss of the subject's self-identity: the verbal sign that stands for the subject - in which the subject posits himself as self-identical - bears the mark of an irreducible dissonance; it never ${ }^{\circ}$ fits' the subject. (Ibid. 46-47)

We could arguably assume that we are born in chaos and the light of the Word is trying to put an order in our existence through our letting us become one with Him and rest in the centre of His holy light. Nevertheless, as we will see in the next part, the lust for the self, the bond of the human being with God as Ground and potentiality could never simply accept the salvation offered by the Word and the overwhelming enlightening unconcealment of our Ground by the Word. This most primordial struggle can only be fought freely, and this is what makes it so terrifying and breathtaking. We are the ones who freely choose who we want to be and where we want to be: in the great shadow of the longing for our own self in the Ground or in the purging flaming of the sacrifice of the self in the light of the Word.

\section{NO LONGER BLIND: FROM THE DEPTHS OF THE GROUND INTO THE LIGHT OF THE WORD}

From what we have seen so far, we understand that the human being as a living being and as the seeker of the meaning of this world, and of his place in it, is caught in the "battlefield" of the struggle between the Ground and the Word. His merging and taking part in this primordial conflict is not limited to the role of a mere observer or a helpless sufferer/witness of the radical changes this struggle generates in the world; on the contrary, the human being is right at the centre of this struggle and his being at the centre of it is what makes human history and progress(?) even more unpredictable and uncontrollable. According to Schelling:

Man, even if born in time, is indeed created into the beginning of the creation (the centrum). The act, whereby his life is determined in time, does not itself belong to time but rather to eternity: it also does not temporally precede life but goes 
through time (unhampered | by it) as an act which is eternal by nature. Through this act the life of man reaches to the beginning of creation; hence, through it man is outside the created, being free and eternal beginning itself. (Schelling 2006, pp. 88)

Man, unlike all the other creatures that coexist in our world, has the unique privilege of having been created in the beginning of the Creation, at the centre of the Creation. This unparalleled state of being is a privilege and, at the same time, a burden whose consequences cannot be grasped solely in thought but run through every single moment of our own existence and endeavour to attribute meaning to the world. Nevertheless, this place of ours at the centre of the existence also bears up against the unbearable consequences of being dragged by both centres: the centre of God's Ground and the centre of His Existence, the blind yearning of the God for Himself and His speaking of the Word of our salvation ${ }^{1}$. This overwhelming ontological struggle of the human being is described by Schelling in the following passage:

But, if through advancing mutation and division of all forces, the deepest and most inner point of initial darkness in a being is finally transfigured wholly into the light, then the will of this same being is indeed, to the extent it is individual, also a truly particular will, yet, in itself or as the centrum of all other particular wills, one with the primal will or the understanding, so that now from both a single whole comes into being. This raising of the deepest centrum into light occurs in none of the creatures visible to us other than man. In man there is the whole power of the dark principle and at the same time the whole strength of the light. In him there is the deepest abyss and the loftiest sky or both centra. The human will is the seed-hidden in eternal yearning-of the God who is present still in the ground only; it is the divine panorama of life, locked up within the depths, which God beheld as he fashioned the will to nature. In him (in man) alone God loved the world, and precisely this likeness of God was possessed by yearning in the centrum as it came into opposition with the light. Because he emerges from the Ground (is creaturely), man has in relation to God a relatively independent principle in himself; but because precisely this principle-without it ceasing for that reason to be dark in accordance with its ground - is transfigured in light, there arises in him something higher, spirit. (Ibid. 32)

From the first moment of our life we live, we act and we breathe as spiritual creatures. The fact that we can exist only as spirits is crucial for our understand-

[1] This constant struggle of the human being between the two centres is lucidly expressed by Jacob Sherman when saying that the subjectivity of the human being is characterized by a centripetal force which brings forth limitation and definition, and by a centrifugal one which tends to expand forever (Sherman 2006, pp. 100) 
ing our own selves. Our selfhood, our emergence from the Ground as creaturely beings is from the outset understood only through its been brought forth into light by the Word. From the very beginning, the ground of our existence, the obscure abyss of the blind will of the yearning God, is enlightened by the Word; that means that our existence and our acting is guided not by a blind will-like a Ground that has not been brought into Light-but, by a lust, a yearning which always knows that it wills something. This will may be the will for the Light of the Word, since the latter has made our willing something possible at the first place or could take the darker path of the willing of the centre of the now enlightened Ground; the yearning for the human being's becoming the centre of the existence. This being in the middle of the struggle between the Ground and the Word is where human being's freedom first arises; that is why Schelling characterizes freedom as "the capacity of doing good and evil (ibid. 23)".

The importance, though, of our being able to choose freely what we want, or what we will to want, is better understood when seen in comparison with the violent split between God's Ground and Existence, His contraction and Self-revealing expansion through the Word. God chose the Word and His contraction is a potentiality lurking deep inside His Ground. In the case of the human being, however, our privilege and our ground-breaking essence of being free is what makes our own selves, and the whole world along us, not only unsteady but purely, and catastrophically, many times, unpredictable for the universe and for our own life. Žižek highlighting the dangers that our being free entails, says:

Here God is in exactly the same position as man on the verge of his timeless act of choosing his eternal character; it is only via this act of primordial decision that God's freedom becomes the actual 'freedom to do Good or Evil' - that is to say, He has to choose between self-withdrawal and opening up, between psychotic madness and the Word. The difference between God and man, of course, is that God inevitably chooses the Good (pronounces the Word, creates Order out of chaos), whereas man no less inevitably incurs the Fall - in both cases, the choice is simultaneously free and 'forced' (Žižek 2007, pp. 33)

From the above passage we can better understand why our being free and the awareness of it have put an extremely heavy weight of responsibility and direness on our shoulders. God has freely chosen to be what He is avoiding the contraction of his Self- withdrawal. On the other hand, the human being, as emerging from a Ground which can only be potentiality in God, manages to make of the Ground a possibility and a result of a freely made choice. There are no safe boundaries that would stop us from deciding our ever-contracting way of being since this freedom of doing so is what ties us to God, even when we are marching far away from Him. In other words, the selfhood which is to 
be found in the Ground is essentially defined by its ever being opposed to the Word that tries to enlighten it and bring it back to Him. Our salvation, our being brought totally in Light and in the transparency of the understanding is eventualized only through the sacrifice of our selfhood, of the will of the Ground, for the sake of our freely choosing the salvation and the tranquillity of the Word. In other words, what the human being strives to do in his whole life is to bring his selfhood, through the action of repetition, the closest possible to the absolute personality of God. Schelling defines personality as "selfhood raised to spirit (Schelling 2006, pp.38)" and this definition alone can make us understand why the human being can never reach in his ontic life the absolute personality that only God has freely decided to emerge as from the depths of His Ground. Namely, the human being, because of his human freedom is tied to the foundation of his Ground; only through the event of his Ground coming into Light can the human being be free to choose not to totally contract himself, but to expand his enlightened selfhood to the acceptance of the Word. Unlike God, human being can never leave behind, as the eternal past, the not having happened actualization of the Will of the Ground. This burden of freedom, this ceaseless violent activity of the human being's living in the split of Ground and Existence in a way radically different from God is explained by Schelling in the subsequent passage:

In the divine understanding there is a system; yet God himself is not a system, but rather a life; and the answer to the question as to [wegen] the possibility of evil in regard to God, for the sake of which the foregoing has been set out, also lies in this fact alone. All existence demands a condition so that it may become real, namely personal, existence. Even God's existence could not be personal without such a condition except that he has this condition within and not outside himself. He cannot abolish the condition because he would otherwise have to abolish himself; he can come to terms with the condition only through love and subordinate it to himself for his glorification. There would also be a ground of darkness in God, if he had not made the condition into his own, bound himself to it as one and for the sake of absolute personality. Man never gains control over the condition, although in evil he strives to do so; it is only lent to him, and is independent from him; hence, his personality and selfhood can never rise to full actuality [zum Aktus]. (Schelling 2006, pp. 99)

The interplay between the selfhood and the personality is of great significance for our understanding the human being's acting, reacting and existing in the world. The dark and the light principle, the Ground and the reception of the light of the Word are interwined in such a way in the human being's essence that their a posteriori setting apart is impossible. The blind Ground found what it wills, the will to remain the ever-contracting centre of the existence, only 
after its being brought into light by the Word. The Word, on the other hand, lent that breath of spirit to the Ground which enabled the latter not only to see through the dark yearning it was trapped in but, in addition, to use its coming into light as the medium for its own becoming what it had, till that point, only blindly longed for, namely itself. Thus, except for the selfhood, the personality as well has contributed to the human being's will of the Word or his Ground. In the next passage we can see more clearly the role and the importance of the personality for the essence of the human being and for the latter's understanding and interpreting the world.

Speaking somewhat metaphorically, Schelling goes on to identify ground with darkness, gravity, contraction, longing and "self-ness", while existence is associated with light, generosity, love, understanding, and universality. These associations reveal to us what is for Schelling the essence of personality, a concept he claims has never yet received sufficient philosophical illumination: to be person is not something simply given in nature, but is rather a kind of achievement, a triumph over nature, an existential transformation of nature. Personality takes on substance, clarity and depth; it acquires strong roots, precisely as a result of this "overcoming" of nature. A person with a weak nature, with no sense of self, will also have a weak personality. The force of personality increases in proportion to the resistance of the nature, the force of "owhnhood", that it must overcome in expressive generosity. (Schindler 2012, pp. 194)

At the conclusion of this part, and before proceeding to the final one on the role and the significance of evil in human lives, we would like to summarize by insisting on the fact that it would be really hard to trace any moral dichotomy in the Freiheisschrift of Schelling since the two principles, the Light and the Dark, the Word and the Ground, are in a constant interplay which is ever-defining both their place in the range of the choices that the human being may be bound to make in his life, and the existence of the human being himself. The human being is not a dialectic expression between the Ground and the Word but the battleground upon which those two fight through the thoughts and actions of the human being. The human being, always dragged to the core of the two principles is not a synthesis, but, rather, a ceaseless struggle of the opposites; of opposites that are what they are only through this opposition. Were there no Word, the Ground would never know what its will is; while without the Ground the Word would not appear as the bringing forth into light of the former. The way the two principles eventuate in the life of the human being is what defines the human being as such: the bearer of an abyssal potentiality, linking him to the event of the the beginning, which knows no limits since the Ground from which he emerges is also unlimited in the human being. While God through the pronunciation of the Word left the Ground and His struggle 
with it-characterized as the vortex of the drives by Žižek (Žižek 2007)- behind as the eternal not actualized Past, the Ground in/through which the human being finds finally the way to actualize his potentiality in the freely taken decision of his trying to reach the Ground's core fomented by his tragic ambition of opposing himself to the centre of the Word and deifying himself in the most obscure centre of the Ground as the new centre of the existence. This terrifying possibility of actualizing what was only meant to be potentiality in God is the heaviest and most dangerous brunt the human being has to bear on his shoulders; a burden that always reminds us that what we really are and what we can be, regardless of how destructive and tragic it may be, is the product of our own choice, of our own freedom.

\section{HUMAN BEING UNBOUND: THE FREEDOM OF (NOT) ACTING EVIL}

In this last part we will essay to show how evil, in the thought of Schelling, far from being a pure deprivation or a merely sensually caused deficiency of the human being-when the senses take the upper hand over Reason's goal of bringing everything into transparency- lies at the very foundation of our possibility of being free. There could be no freedom for the human being without evil since the existence of evil is what makes the human being able to choose between himself becoming enlightened by the Word or giving in to the contraction of his further annihilating existence, as the imposed want-to-be centre of the universe, a contraction which, as we have already seen, is the Ground's passage from blind willing to a concrete, brought into light lusty willing for itself. Schelling in the passage coming after explains in a very thorough manner how evil can be comprehended in relation to the will of the two principles, the Ground and the Word:

The general possibility of evil consists, as shown, in the fact that man, instead of making his selfhood into the basis, the instrument, can strive to elevate it into the ruling and total will and, conversely, to make the spiritual within himself into a means. If the dark principle of selfhood and self-will in man is thoroughly penetrated by the light and at one with it, then God, as | eternal love or as really existing, is the bond of forces in him. But if the two principles are in discord, another spirit usurps the place where God should be, namely, the reversed god, the being aroused to actuality by God's revelation that can never wrest actuality from potency, that, though it never is, yet always wants to be and, hence, like the matter of the ancients, cannot be grasped actually (actualized) by the complete understanding but only through the false imagination (logism -oi noth -oi*), which is sin itself; for this reason, since, having no Being itself, it borrows the appearance of Being from true Being, as the serpent borrows colors from the light, it strives 
by means of mirrorlike images to bring man to the senselessness in which it alone can be understood and accepted by him. (Schelling 2006 pp. 54)

Evil, thus, is tied in with the will of the human being in an indissoluble way for the glorification of his own self. It is a discord- between the principles and the two centres of Ground and Word- and a false imagination having, nevertheless, very real, undoubtedly, and concrete effects. Its falseness does not reside, solely, in a moral discourse indicating that the dark principle can never dominate the world since that would jeopardize the progress of Reason through human history nor in the philosophical/ontological necessity of maintaining the two principles so that the struggle may never end. In our opinion, what lies at the core of Schelling's analysis of evil is the suffering of the human being who, despite his emergence from the Ground of God, does not realize that he can never become God no matter how far the actualization of the potentiality of the Ground will go. The human being can never exist as God; the Ground inside the human being could never dominate the light of the Word so as to become the new personal revelation of the Hybris of the human being. Human being can only strive till death, literally, to prove to himself that he can become God when he finally understands that his only way of coming close to God is exactly the other way round: not the uprising of his selfhood against the flame's "threat" of the Word's revelation, but, on the contrary, through willingly sacrificing his selfhood in the purging fire of the Word where the selfhood reaches its highest peak of existence when it finally gets a glimpse of its origin at the beginning of the Creation. Consequently, only through the sacrifice and the purging of the selfhood in the Word could the highest personality, the closest possible to God, ever emerge as a reborn will for the centre of the Word.

Although the endeavour of the human being to become God/the centre of the universe is never going to come to fruition due to the incapacity of his Ground to get actualized as the existing perfect God, this does not mean that our world is destined to be a place of permanent peace and of the dominance of the understanding of the Word. Schelling in his analysis of the indivisible remainder sets forth in a brilliant way how our world is open to many different and obscure, if not chaotic, possibilities:

After the eternal act of self-revelation, everything in the world is, as we see it now, rule, order and form; but anarchy still lies in the ground, as if it could break through once again, and nowhere does it appear as if order and form were what is original but rather as if initial anarchy had been brought to order. This is the incomprehensible base of reality in | things, the indivisible remainder, that which with the greatest exertion cannot be resolved in understanding but rather remains eternally in the ground. (Schelling 2006, pp. 29) 
Žižek commenting on this passage brings the thought of Schelling to its extreme ontological consequences saying:

When we repeat after Schelling that every Order arises on the basis of and has its roots in a general Disorder, we are therefore not making the usual relativist point that man's ordering activity is limited to local attempts to introduce a minimum of Order into the wide ocean of primordial chaos - to attempts which, as such, are ultimately doomed to fail; our point is, rather, that the very imposition of an Order is an act of supreme violence - Order is a violent imposition which throws the universe out of joint. Disorder is the condition of possibility of Order not only in the sense that the very notion of Order is conceivable only against the background of general Disorder, as a series of local attempts to limit the Disorder - the highest Disorder, the highest violation of 'natural balance', is the very imposition of a (biased) Order. (Žižek 2007, pp. 76)

Žižek, based on his interpretation of Schelling, is presenting a very disturbing, plausible, nevertheless, view of the world. The necessity of the human being to bring everything into Order, to impose a structure and to find meaning in a perfectly harmonious whole does not necessarily entail that he is answering to call of the Origin in order to make possible the restoration of the transparency in his being guided by the Reason. Probably the absolute transparency is not possible and every effort to bring the world to its transparency is a deeper glimpse of horror in the abyss of the Ground. In other words, even though evil is not Being, as Schelling has clearly mentioned above, this does not deprive it from the possibility of dragging the world down to an absolute chaos where the will of the Ground brings every human being to its centre. What might rise as a rather interesting question is not why evil exists or not, but, quite the opposite, how good and the revelation of the Word could ever be possible in a world dominated by the no longer blinded will of the Ground. If we see our existence like that, namely, out of the teleological context of the dominance of Reason in this actual world, then we would probably find out that evil is giving us the possibility of searching for the beacon of the Word's light in a world where chaos rules and the Order is the intruder. The Word, thus, grows to be more than the simple counterpart of the dark principle of the Ground; it becomes the quintessence of the struggle of a being who even though he could be totally dominated by the contraction of the centre of the Ground and by his lust for the deification of his own selfhood, he, nevertheless, seeks the light of the Word; not, though, as a light which enlightens and opens the path of vision for his most egotistic desires and ambitions but as the flame in which the centre of the Ground, the core of his own selfhood, may finally be purged and blazingly enlightened in Spirit while tracing his way back to the abyssal freedom where 
the opposition of the principles can no longer be seen as opposition and struggle but as a harmonious co-being in the indifference of the Absolute.

\section{CONCLUSION}

Having reached the conclusion of this paper we would like to more emphatically stress why, from our point of view, the Freiheitsschrift of Friedrich Schelling is a work of titanic proportions in the course of the modern philosophy; a work that Martin Heidegger characterized as "one of the few essentials of philosophy's history (Heidegger 2016, pp. 358)"2. Throughout the whole text Schelling is making a constant appeal to the human being so that the latter may finally decide who he really is and which his decision concerning his existence in the world is. What makes this already hard decision even harder is that it is made founded on the existential "burden" of freedom. The human being deciding who he is and who he wants to be is freely deciding concerning his own being, knowing that he is not driven by blind impulses of the Ground-since the latter has been enlightened by the Word, finding thus concrete things to will for- nor by a direct freedom violating intervention of the Word in his every step. Through the bringing forth into light of the Ground by the fire of the Word both principles have appeared in their shining brilliance to the human being. The human being, thus, now freely decides what he is. This decision, though, is of immeasurable proportions since it may lead the human being to wage his war against the only centre of the world, the revelation of the Word. The human being is the only being of the Creation who has the potentiality of raising himself against the Word, claiming to become the centre of the Creation. The human being is the only one who can freely decide to set himself against God and the Creation, demanding his own becoming the crown of the universe $e^{3}$. This potentiality, regardless of its being fruitless and vain, as we have seen before, is still proof of our connection with God; a connection which could lead to our own freely made decision of daring God even though we are only mortals. Schelling, thus, reaching abysmal depths of the psyche ${ }^{4}$ of the human being by demonstrating how the afore mentioned daring can

[2] The interest of Martin Heidegger on this specific work of Schelling is also reflected on the fact that in 1936 he dedicated to the analysis of the latter lectures aa the University of Freiburg. See: Heidegger 1985

[3] Michelle Kosch makes a very interesting remark concerning freedom and evil when saying "Recall that Schelling thought that, because the ground of freedom is also the ground of the possibility of $\sin$ (namely the element of independence of the finite self) the first use of freedom is always a drawing away from God (Kosch 2006: 212)"

[4] For more information concerning Schelling's influence on our conception of the psyche and the unconscious see: McGrath 2012 and Ffytche 2013. 
really be carried out, has brought evil into our view in a very different, much more personal and humane way. Acting evil is the price of our acting freely, but still, it has opened a breach in this seemingly chaotic and impulsive world of freely deciding to act good and freely sacrificing our centre of the Ground, our obscure selfhood, in the flame of the Word. Schelling has fought hard to demonstrate in his Freiheitsschrift that under the apparent dominance of evil's emergence in the human arrogance, the seed of the salvation of the human being is safeguarded, through his acting in accordance with the revelation of the Word. An acting which brings us closer to God we have emerged from, but most importantly, an acting which gives rise to a salvation freely chosen.

\section{REFERENCES}

Ffytche, M. 2013. The Foundation of the Unconscious: Schelling, Freud and the Birth of the Modern Psyche. Cambridge: Cambridge University Press

HeIDEGGER, M. 1985 Schelling's treatise on the essence of the human freedom (Tr. by Joan Stambaugh). Ohio: Ohio University Press

Heidegger, M. 2016 Ponderings II-VI (Tr. by Richard Rojcewicz). Bloomington: Indiana University Press.

McGrath, S. 2012 The dark ground of spirit. London: Routledge

Michelle, K. 2010 Freedom and reason in Kant, Schelling, and Kierkegaard. Oxford: Oxford University Press

SCHELling, F. 2006 Philosophical Investigations Into the Essence of Human Freedom (Tr. by J. Love and J. Schmidt). Albany: State University of New York Press

Sherman, J..H. $<<$ A genealogy of participation $>>$ in J.N. Ferrer and J.H. Sherman (eds) The Participatory Turn: Spirituality, Mysticism, Religious Studies. Albany: State University of New York Press.2008 pp. 81-112

SCHINDLER, D.C. 2012 The perfection of freedom. Eugene: Cascade Books

ZIZEK, S. 2007 The indivisible remainder: An Essay on Schelling and Related Matters. London: Verso 
